DOI

\author{
${ }^{\odot}$ А. О. Біволаріу, І. В. Каліновська
}

ВДНЗ України «Буковинсъкий державний медичний університет», Чернівці

\title{
КАРДІОТОКОГРАФІЧНІ ЗМІНИ У ВАГІТНИХ З ВАГІТНІСТЮ БІЛЬШЕ 40 ТИЖНІВ
}

КАРДІОТОКОГРАФІЧНІ ЗМІНИ У ВАГІТНИХ З ВАГІТНІСТЮ БІЛЬШЕ 40 ТИЖНІВ. У статті наведено дані кардіотокографрічних змін стану внутрішньоутробного плода у вагітних з вагітністю більше 40 тижнів. Найчутливішими показниками, що віддзеркалюють стан плода, є амплітуда миттєвих осциляцій, кількість, амплітуда і тривалість акцелерацій і децелерацій та тривалість стабільного ритму.

КАРДИОТОКОГРАФИЧЕСКИЕ ИЗМЕНЕНИЯ У БЕРЕМЕННЫХ С БЕРЕМЕННОСТЬЮ БОЛЕЕ 40 НЕДЕЛЬ. В стаТЬе ПреДставлены данные кардиотокографических изменений состояния внутриутробного плода у беременных со сроком более 40 недель. Наиболее чувствительными показателями, которые отображают состояние плода, есть амплитуда мгновенных осцилляций, количество, амплитуда и продолжительность акцелераций и децелераций, а также продолжительность стабильного ритма.

CARDIOTOCOGRAPHIC CHANGES IN PREGNANT WOMEN OF MORE THAN 40 WEEKS. The paper presents the data of cardiotocographic changes of the condition of the intrauterine fetus in pregnancy more than 40 weeks. The most sensitive parameters, reflecting the condition of a fetus, are the amplitude of instant oscillations, the number, the amplitude and duration of accelations and decelerations, as well as the duration of stable rhythm.

Ключові слова: кардіотокограма, вагітність, плацентарна дисфрункція.

Ключевые слова: кардиотокограмма, беременность, плацентарная дисфункция.

Key words: cardiotocogram, pregnancy, placental insufficiency.

ВСТУП. Основною причиною ускладненого перебігу вагітності і пологів, перинатальної захворюваності і смертності $€$ плацентарна дисорункція [1]. Порушення морфрофункціонального стану плаценти при вагітності більше 40 тижнів пригнічують компенсаторнопристосувальні можливості системи мати-плацента-плід, уповільнюють розвиток плода [2, 3]. Для діагностики плацентарної дисфункції використовуються різні методи обстеження вагітних, одним із яких $є$ кардіотокографрічне дослідження стану внутрішньоутробного плода [4].

Мета дослідження - виявити особливості кардіотокографічних змін у вагітних 3 вагітністю більше 40 тижнів.

МАТЕРІАЛИ ТА МЕТОДИ. ДЛя виконання поставленої мети проведено кардіотокографічне обстеження у 30 вагітних із вагітністю більше 40 тижнів та здорових вагітних в терміні вагітності 39-40 тижнів. Основну групу склали 20 вагітних 3 вагітністю більше 40 тижнів. Вік обстежених складав від 20 до 36 років. Першовагітних було - 15 (75\%), повторновагітних - 5 (25\%). Супутні захворювання спостерігались у 16 жінок (80\%), анемія І ступеня - в 11 осіб (55\%), хронічний пієлонефрит - у 6 пацієнток (30\%). Групу контролю склали 10 здорових вагітних, без проявів плацентарної недостатності та переношування вагітності. Ретроспективний аналіз показав, що у вагітних обстеженої групи в 73 \% спостерігались явища загрози переривання вагітності та в $82 \%$ - у попередніх вагітностях. У 26,6 \% вагітність супроводжувалася кровомазанням у ранньому ембріональному періоді та частковим відшаруванням хоріона. У 11,2 \% випадків у вагітних в анамнезі були відмерлі вагітності в терміні до 10 тижнів. 3 метою виявлення особливостей змін стану внутрішньоутробного плода всім вагітним проведено кардіомоніторне обстеження.
РЕЗУЛЬТАТИ ДОСЛІДЖЕННЯ ТА ЇХ ОБГОВОРЕННЯ. Всього виконано 30 кардіотокографрічних спостережень. Як видно з таблиці 1, рівень базального ритму серцебиття плода у вагітних контрольної групи - стабільний, у межах 140-160 уд./хв. У вагітних із переношеною вагітністю (основна група) була зміна базальної частоти серцебиття (БЧСС) в бік тахікардії ( $p>0,05)$, однак у 34,5 \% випадків цей показник перебував на рівні 120-130 - 150-160 уд./хв. Стійка брадикардія виявлялася дуже рідко (0,2% випадків).

Характеристика базальної частоти доповнюється оцінкою варіабельності, що відображає реактивність автономної нервової системи плода [5]. При вагітності більше 40 тижнів та розвитку плацентарної дисфункції амплітуда миттєвих осциляцій (АМО), порівняно 3 нормою, зменшувалася, і кардіотокограма часто мала

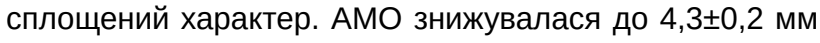
$(p<0,001)$ у вагітних основної групи. Отримані дані підтверджують, що чим більш характер осциляції наближається до монотонного, тим тяжчі гіпоксичні порушення плода. Акцелерації як показник стабільного функціонального стану плода, у групі здорових вагітних (контрольна

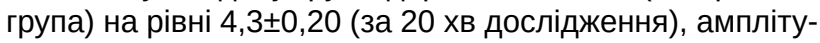
да $-24,3 \pm 0,9$ і тривалість - 11,6 \pm 04 с. Порівняно 3 контролем кількість акцелерацій у жінок з терміном вагітності

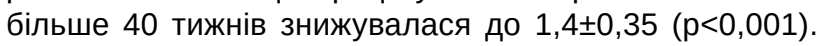

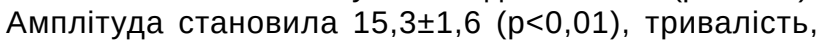

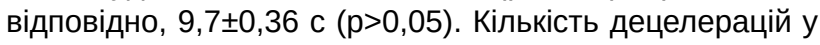
контрольній групі була незначною - 1,5 0,5 (за 20 хв дослідження), амплітуда і тривалість відповідали 16,3 $\pm 1,2$

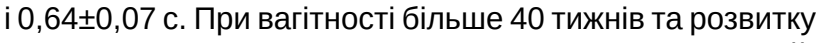
плацентарної дисфункції зміни кількості децелерацій, амплітуди і тривалості вірогідні і складали, відповідно, $4,2 \pm 0,23$ ( $p<0,001), 24,5 \pm 1,6$ мм $(p<0,05)$ і $3,50 \pm 0,33$ с $(p<0,001)$. Виражена гіпоксія при рухах плода і скорочення 


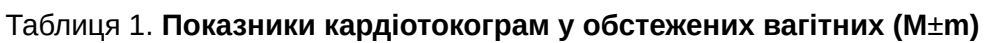

\begin{tabular}{|c|c|c|c|}
\hline \multirow{2}{*}{\multicolumn{2}{|c|}{ Показники КТГ }} & \multicolumn{2}{|c|}{ Групи вагітних } \\
\hline & & $\begin{array}{c}\text { фрізіологічна } \\
\text { вагітність (контроль) }(\mathrm{n}=10)\end{array}$ & $\begin{array}{c}\text { основна група } \\
(n=20)\end{array}$ \\
\hline \multicolumn{2}{|c|}{ Базальна частота серцебиття (уд./хв) } & $146,2 \pm 1,30$ & $175,6 \pm 2,40^{*}$ \\
\hline \multicolumn{2}{|c|}{ Амплітуда миттєвих осциляцій (мм) } & $11,2 \pm 0,43$ & $4,3 \pm 0,20^{*}$ \\
\hline \multirow[t]{3}{*}{ Акцелерації } & Кількість & $4,3 \pm 0,20$ & $1,4 \pm 0,35^{\star}$ \\
\hline & Амплітуда (мм) & $24,3 \pm 0,90$ & $15,3 \pm 1,60^{*}$ \\
\hline & Тривалість (с) & $11,6 \pm 0,46$ & $9,7 \pm 0,36^{*}$ \\
\hline \multirow[t]{3}{*}{ Децелерації } & Кількість & $1,5 \pm 0,5$ & $4,2 \pm 0,23^{*}$ \\
\hline & Амплітуда (мм) & $16,3 \pm 1,20$ & $24,5 \pm 1,60^{*}$ \\
\hline & Тривалість (с) & $0,6 \pm 0,07$ & $3,5 \pm 0,33^{*}$ \\
\hline \multicolumn{2}{|c|}{ \% стабільного ритму } & $18,3 \pm 1,20$ & $59,8 \pm 3,90^{*}$ \\
\hline
\end{tabular}

Примітка. * - статистична різниця між показниками в групах із фрізіологічною вагітністю і вагітністю більше 40 тижнів $(p<0,05)$.

матки виявлялася реакцією серцево-судинної системи у вигляді пізніх децелерацій. Стабільний ритм - тип варіабельності кардіотокограм, характеризується відсутністю акцелерацій і децелерацій. При нормальному стані плода тривалість стабільного ритму складала в середньому $18,3 \pm 1,2 \%$. У випадку вагітності більше 40 тижнів та розвитку дистресу плода тривалість стабільного ритму значно зростала і становила 59,8 $33,9 \%(p<0,001)$. Отже, для фрізіологічного стану плода характерний ундулюючий або злегка ундулюючий (при відхиленні від середніх значень БчСС на 0-5 уд.) типи варіабельності кардіотокограм із коливанням БЧСС від 110 до 170 уд./хв, наявністю акцелерацій. Порушення більшості параметрів кардіотокограм виявлялися при вагітності більше 40 тижнів зниженням AMO, зменшенням кількості і якості акцелерацій, поряд зі збільшенням децелерацій, зростанням відсотка стабільного ритму зі значними ділянками монотонності і синусоїдального ритму. Власні результати підтверджують, що сальтаторний тип варіабельності (при відхиленні від середніх значень БчСС на 10-25 уд./Хв) також може бути ознакою дистресу плода при вагітності більше 40 тижнів та розвитку плацентарної дисфрункції. Необхідно відзначити, що в групі здорових вагітних, у 3,5 \%, за даними кардіотокограм, відзначалося зниження компенсаторнопристосувальних можливостей плода, тоді як стан матері, матково-плацентарного комплексу й у подальшому, стан немовляти, цього не підтверджували. В основній групі в 89,1 \% випадків у вагітних 3 вагітністю більше 40 тижнів показники кардіотокограм свідчили про наявність дистресу плода.

ВИсновки. Показниками, що відображають стан плода при вагітності більше 40 тижнів, $є$ амплітуда миттєвих осциляцій, кількість, амплітуда і тривалість акцелерацій і децелерацій та тривалість стабільного ритму. Дані кардіотокограм дозволяють своєчасно діагностувати або запідозрити несприятливі умови фрормування плода та вибрати правильну акушерську тактику.

ПЕРСПЕКТИВИ ПОДАЛЬШИХ ДОСЛІДЖЕНЬ. ВИвчення змін матково-плацентарного і плодового кровотоку у вагітних 3 вагітністю більше 40 тижнів дозволить прогнозувати ризик виникнення дистресу плода та своєчасно розродити вагітну.
СПИСОК ЛІТЕРАТУРИ

1. Дашкевич В. Є. Плацентарна недостатність: сучасні аспекти патогенезу, діагностики, профрілактики та лікування / В. Є. Дашкевич, С. М. Янюта // Мистецтво лікування. - 2011. - № 4. - С.22-25.

2. Стрижаков А. Н. Физиология и патология плода / А. Н. Стрижаков. - М. : Медицина, 2011. - 356 с.

3. Резніченко Г. І. Патогенетичні та клінічні аспекти хронічної плацентарної недостатності, профрілактика і лікування / Г.І.Резніченко, Ю. М. Бесарабов // Запоріжський мед. журн. - 2013. - № 2. - С. 76-79.

4. щербаков А. Ю. Морфоорункциональные особенности плаценты при невынашивании беременности различной этиологии / А. Ю. Щербаков, Д. Г. Сумцов // Междунар. мед. журн. - 2013. - № 2. - С. 65-68.

5. Callen P. W. Ultrasonography in obstetrics and gynecology / P. W. Callen. - WB Saunders company, 2013. $-1078 p$. 